\title{
New records and range extension of Black-goggled Tanager, Trichothraupis melanops (Vieillot, 1818) (Passeriformes, Thraupidae), in extreme southern Brazil
}

\author{
Gustavo Crizel Gomes ${ }^{1}$, Thales Castilhos de Freitas ${ }^{2}$, Henrique Noguez da Cunha ${ }^{3}$, \\ Fernando P. Jacobs ${ }^{4}$, Michele Spenst Wall ${ }^{5}$
}

\begin{abstract}
1 Universidade Federal de Pelotas, Programa de Pós-Graduação em Desenvolvimento Territorial e Sistemas Agroindustriais, Av. Eliseu Maciel (sn), Campus Capão do Leão, CEP: 96010-900, Capão do Leão, RS, Brazil. 2 Universidade Federal de Pelotas, Programa de Pós Graduação em Ciências Ambientais, Centro de Engenharias, Rua Benjamin Constant, CEP: 96010-020, Pelotas, RS, Brazil. 3 Universidade Federal de Santa Maria, Programa de Pós-Graduação em Geografia, Av. Roraima, 1000, Cidade Universitária, CEP: 97105-900, Santa Maria, RS, Brazil. 4 Birdwatching guide and Independent researcher, Rua Novo Hamburgo, 1821, CEP: 96090-470, Pelotas, RS, Brazil. 5. Universidade da Região da Campanha, Centro de Ciências da Saúde, Av. Tupy Silveira, 2099, CEP: 96400-110, Bagé, RS, Brazil.

Corresponding author: Gustavo Crizel Gomes, crizelgomes@gmail.com
\end{abstract}

\begin{abstract}
We describe new records of Trichothraupis melanops in five municipalities of Rio Grande do Sul, Brazil. The birds were detected in sporadic expeditions in the Serra do Sudeste and Campanha Gaúcha regions by direct visualization and vocal recognition. One of these records, next to the border with Uruguay, is the southernmost known location for the species in Brazil. This record expands the geographic range of the species in Brazil south by $170 \mathrm{~km}$. We believe that these occurrences are seasonal displacements and do not represent a colonization front with resident populations.
\end{abstract}

\section{Keywords}

Frutero Corona Amarilla, geographic distribution, Lanio melanops, Pampa biome birds, seasonal displacements, tiê-de-topete. melanops (Vieillot, 1818) (Passeriformes, Thraupidae), in extreme southern Brazil. Check List 16 (1): 67-73. https://doi.org/10.15560/16.1.67

\section{Introduction}

Trichothraupis Cabanis, 1850, is a monospecific genus consisting of the Black-goggled Tanager, Trichothraupis melanops (Vieillot, 1818). The species has forest habitat, living in the understory of old-growth and second-growth forests (Fávaro and Anjos 2005; BirdLife International 2016). Individuals are seen alone, in pairs, or in small groups. They constitute mixed-species bird flocks, acting as a nuclear species (Faria and Rodrigues
2009). They mainly feed on arthropods and occasionally on fruits (Hilty 2019). This tanager is apparently resident throughout its area of occurrence, considered scarce to locally abundant (Belton 1994; Hilty 2019). The conservation status of this species is Least Concern (BirdLife International 2016).

Trichothraupis melanops occurs in Brazil from Bahia to Rio Grande do Sul, and also in Argentina, Paraguai, Bolivia, and Peru (BirdLife International 2016). There is a lack of documental evidence about its occurrence in 
Uruguay (Azpiroz et al. 2012). In the state of Rio Grande do Sul, it occurs from the Southern Brazilian Plateau as far as the northern border of the Central Depression, with records in the northern part of the Coastal Plain. Costa (2005) ruled out the possibility of it occurring in the Campanha region.

The originally accepted southern limit of distribution of T. melanops in Brazil was Viamão municipality. Individuals have been recorded in two protected natural areas there: the Itapuã State Park (Belton 1984, 1994) and the Banhado dos Pachecos Wildlife Refuge, a few kilometers north (Accordi and Hartz 2006).

Marateo et al. (2009) mentioned two records of $T$. melanops (2004 and 2005) in El Palmar National Park, Colón municipality, Entre Ríos Province, Argentina. These are the southernmost records for the species. However, the distribution map suggested by BirdLife International and adopted by IUCN (BirdLife International 2016) was not altered to include those records.

We document new records of $T$. melanops in the extreme southern limits of Brazil, establishing a new southern limit of occurrence in Brazil for T. melanops.

\section{Methods}

Between 2015 and 2018 we and our collaborators performed sporadic research/photographic expeditions in the regions Serra do Sudeste and Campanha Gaúcha, Rio Grande do Sul, Brazil. The purpose of these expeditions was to elaborate bird species lists and make photographic records.

The birds were recognized by direct visualization and vocal recognition. In all localities the species was casually recorded and the individuals were photographed. No attraction methods (e.g. playback or baits) were used to record the birds. The minor distance between two localities of data collection was $41 \mathrm{~km}$.

One audio recording of $T$. melanops was obtained using a smartphone coupled with a parabolic microphone reflector (SONY PBR-300). The vocalization of two individuals was captured with the voice recorder app HI-Q MP3 REC 2.7.1 in high-fidelity Waveform Audio File Format (encoding: PCM uncompressed; sample rate $48000 \mathrm{~Hz}$; sample size: 16 bits). Vocalizations were emitted spontaneously (contact calls) while birds foraged. A sonogram and spectrogram were obtained with the sound editor software Raven Lite 2.0.1. (Bioacoustics Research Program. 2016) (Fig.1).

The Serra do Sudeste, also named Escudo Sul-RioGrandense, is a dissected plateau, characterized by undulating relief of elevations between 200 and $500 \mathrm{~m}$. The vegetation type is grassland-forest mosaic with the presence of steppe, savanoid vegetation and semi-deciduous seasonal forest (Teixeira et al. 1986; Pillar et al. 2009). The region's climate type is humid subtropical climate (Cfa) according to the Köppen classification (Alvares et al. 2013).

The Campanha region is characterized by flat to gently undulating topography with elevations between 140 and $220 \mathrm{~m}$ (Ab'Saber 1969). Its vegetation presents a predominance of grasslands permeated with shrublands and low growing forests that are poor in species richness and restricted to banks of watercourses (Teixeira et al. 1986). The region's climate type is also considered (Cfa) (Alvares et al. 2013).

Geographic coordinates were obtained using a Garmin GPSMAP64 GPS receiver using the WGS84 datum. To create the geographic distribution map (Fig. 2) we used ArcGIS v. 10.2.2 (ESRI 2014). We inserted the IUCN suggested geographic range (BirdLife International 2016), the points of the previous southernmost known locations (Belton 1994; Marateo et al. 2009), and the new records. Finally, we drew a minimum convex polygon, as indicated by the IUCN to calculate the Extent of Occurrence (EOO; IUCN Red List Technical Working Group 2019), to encompass our new records, the southernmost known occurrence of the species (Marateo et al. 2009), and the geographic range suggested by IUCN (BirdLife International 2016).
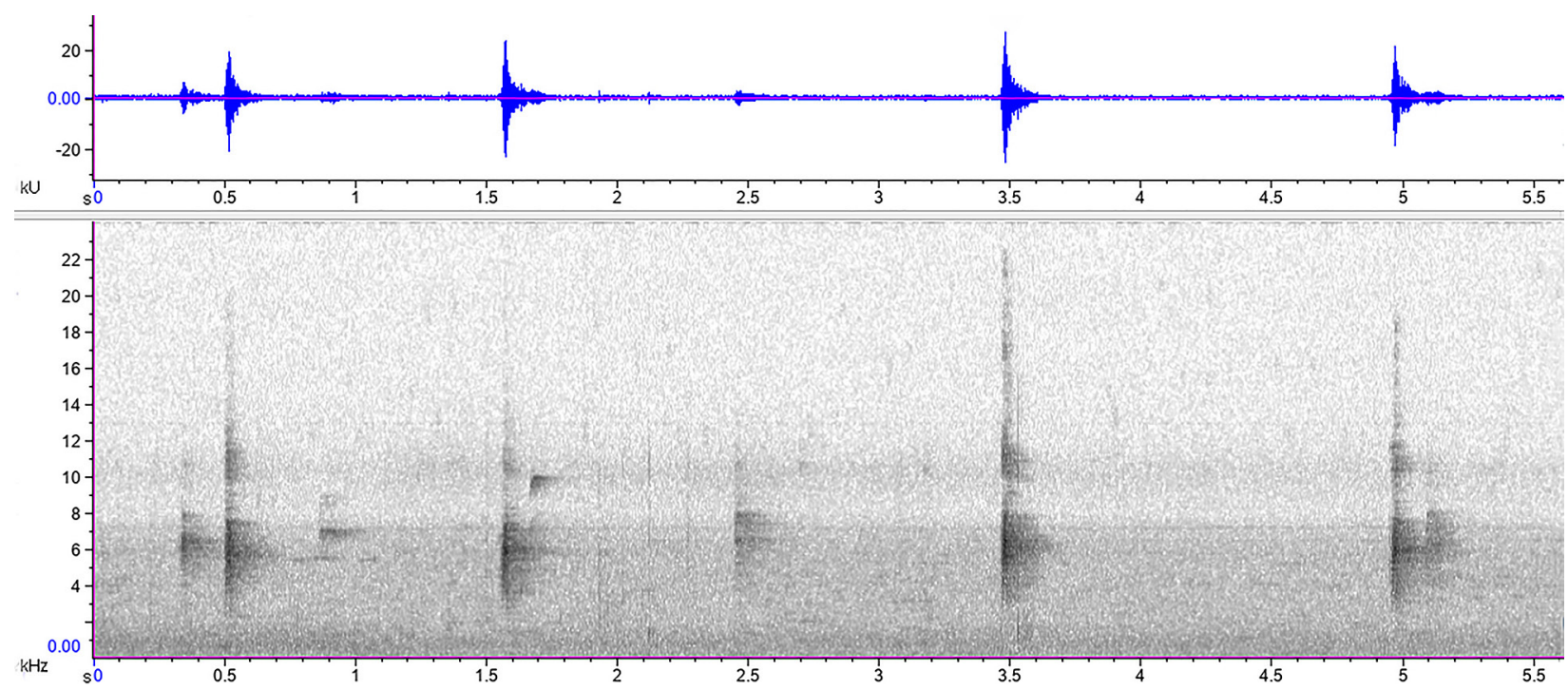

Figure 1. Spectogram and sonogram of two individuals of Trichothraupis melanops recorded in Pelotas, Rio Grande do Sul State, Brazil. 

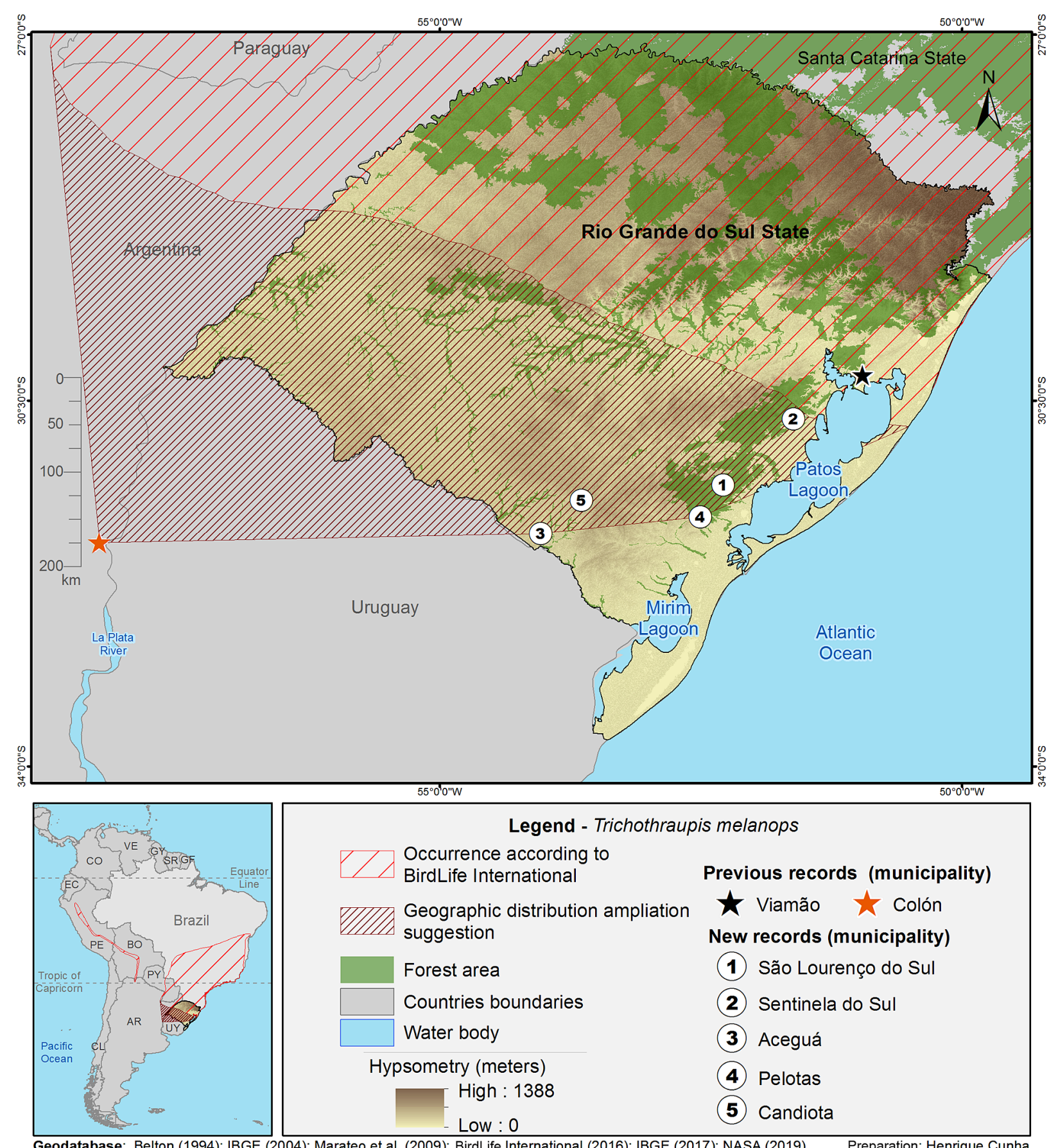

Geodatabase: Belton (1994); IBGE (2004); Marateo et al. (2009); BirdLife International (2016); IBGE (2017); NASA (2019). Geographic coordinates system. Datum WGS84

Figure 2. Distribution range with the previous southernmost known localities (stars), the new records (numbered white circles) and a polygon suggesting an ampliation in the geographic distribution, considering our new records and Marateo et al. (2009).

We searched for occurrence records in the following databases: Global Biodiversity Information Facility (https://www.gbif.org), SpeciesLink (http://www.splink. org.br), eBird (https://ebird.org), EcoRegistros (http://www. ecoregistros.org), Xeno-Canto (https://www.xeno-canto. org), WikiAves (https://www.wikiaves.com.br), and Portal de Periódicos Capes (http://www.periodicos.capes.gov.br).

\section{Results}

New records. Brazil -1 adult ${ }^{7}$; Rio Grande do Sul, São Lourenço do Sul, Picada Quevedos; $31^{\circ} 18.65^{\prime} \mathrm{S}, 052^{\circ}$ $17.33^{\prime} \mathrm{W}$; 20 Jun. 2015; observed by GCG and Raphael Kurz (Fig. 3A; photographic record available at WikiAves as WA1731422); solitary individual observed at edge of semi-deciduous seasonal forest fragment within a mosaic of agricultural areas with abandoned pastures and forest fragments (Fig. 4A). 1 adult $\$$; Rio Grande do Sul, Sentinela do Sul, Passo Grande; 30 40.05’S, $051^{\circ} 36.96^{\prime} \mathrm{W}$; 9 Jul. 2017; observed by Julianita D. Moraes (Fig. 3B; photographic record available at WikiAves as WA2631560); in mixed-species flocks in the high canopy of Eucalyptus trees, in an area characterized by predominance of bovine cattle pastures, permeated 

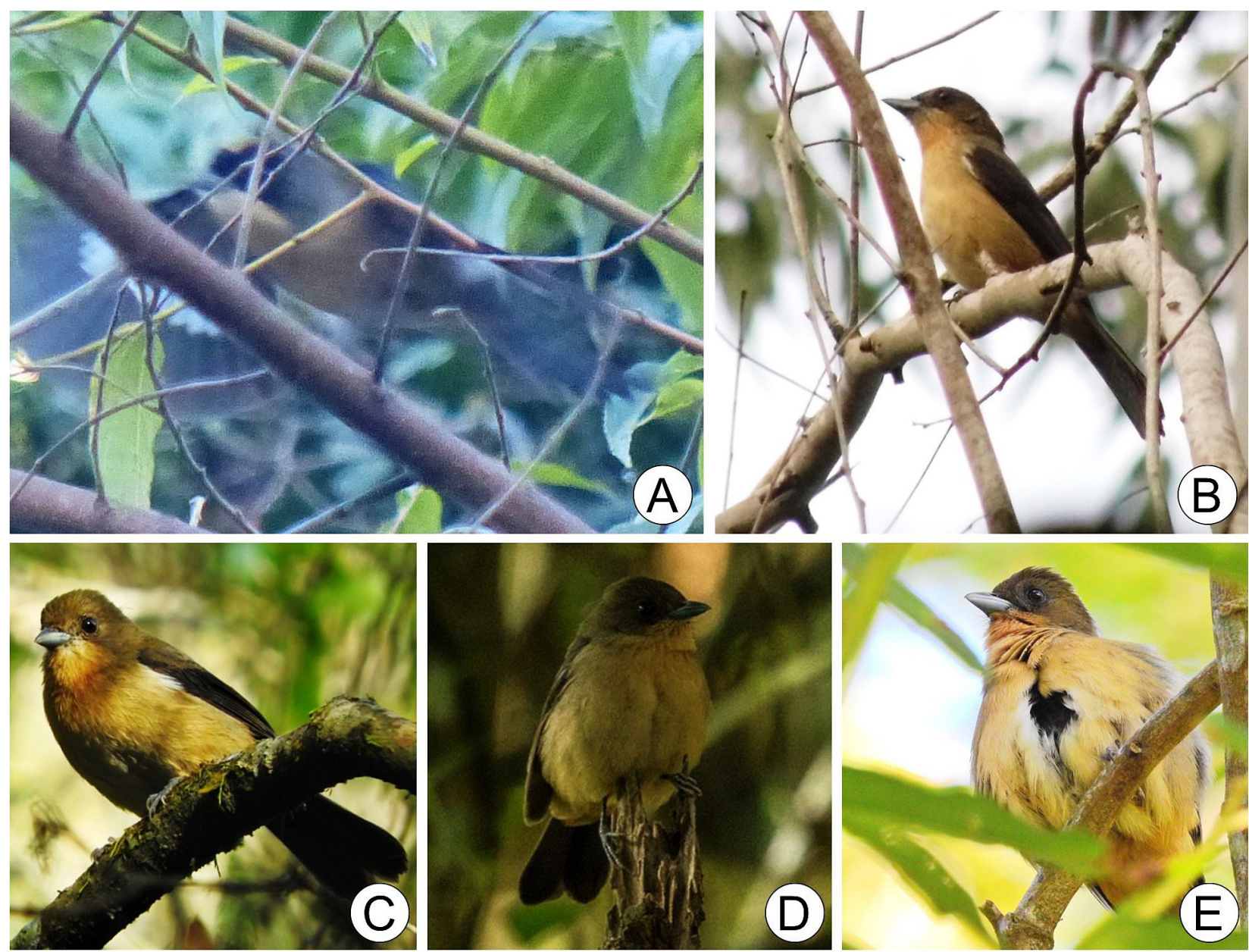

Figure 3. Photographic records of the individuals reported in the following municipalities: A. São Lourenço do Sul. B. Sentinela do Sul. C. Aceguá. D. Pelotas. E. Candiota. Photographs by GCG, Julianita D. Moraes, Adolph Wall, FPJ, and Rudimar de Matos, respectively.

with secondary forest fragments and silviculture forests (Fig. 4B). • 1 adult +; Rio Grande do Sul, Aceguá, Colônia Pioneira; $31^{\circ} 46.55^{\prime} \mathrm{S}, 054^{\circ} 02.35^{\prime} \mathrm{W}$; between 3 Jun. and 1 Set. 2018; observed by Adolf Wall and MSW (Fig. 3C; photographic records available at WikiAves as WA2992271; WA2993370; WA3011482; WA3016961; WA3026153). Possible all the records are of the same female, for it was seen for the first time in the riparian forest of Jaguarão Chico stream; all the following records are within $200 \mathrm{~m}$ of site, in the garden trees of a farm's main house. The locality is characterized by agricultural production, flat terrain and mainly grasslands with low riparian forests, typical of the Pampa Biome (Fig. 4C). 2 adults क; Rio Grande do Sul, Pelotas, Cascata; $31^{\circ} 36.91^{\prime} \mathrm{S}, 052^{\circ} 30.43^{\prime} \mathrm{W}$; 8 Jun. 2018; observed by FPJ (Fig. 3D; photographic record available at WikiAves as WA2998346; audio recording available at Xeno-canto as XC484407); foraging in mid-level of forest edge with a couple of Tachyphonus coronatus (Vieillot, 1822); apparently, all others followed the adult male of this latter species; on a road that crosses a degraded semi-deciduous forest fragment, near a couple of human houses (Fig. 4D). - 1 adult $\odot$; Rio Grande do Sul, Candiota, Vila Operária; $31^{\circ} 27.35^{\prime} \mathrm{S}, 053^{\circ} 38.93^{\prime} \mathrm{W}$; 16 Aug. 2018; observed by Rudimar de Matos, (Fig. 3E; photographic record available at WikiAves as WA3074263); in mixedspecies bird flock near Candiota stream; riparian vegetation of shrubs and small trees, between grasslands and Eucalyptus plantations (Fig. 4E).

Identification. Trichothraupis melanops is characterized by its conspicuous plumage in relation to other species of tanagers. The male presents a dark grey back, black wings and tail and cinnamon underparts. It also presents an extense yellow crest, which contrasts with a black mask, and a bluish beak. The female does not present the black mask and it does present a smaller yellow crest. The immature does not present yellow on the crown. Male and female present a white wingband, visible in flight (Fig. 3A) (Hilty 2019; Narosky and Yzurieta 2010; Timm and Timm 2016).

\section{Discussion}

The avifauna of Serra do Sudeste and Campanha Gaúcha has been studied since the 1970s (Belton 1984, 1994; Mauricio and Dias 1998, 2001; Efe et al. 2010; Corrêa et al. 2012; Corrêa et al. 2013; Seixas et al. 2014; Bergmann et al. 2015) without finding T. melanops. Hermann von Ihering, who lived for seven years (1885-1892) in São Lourenço do Sul municipality (Lopes and Podgorny 


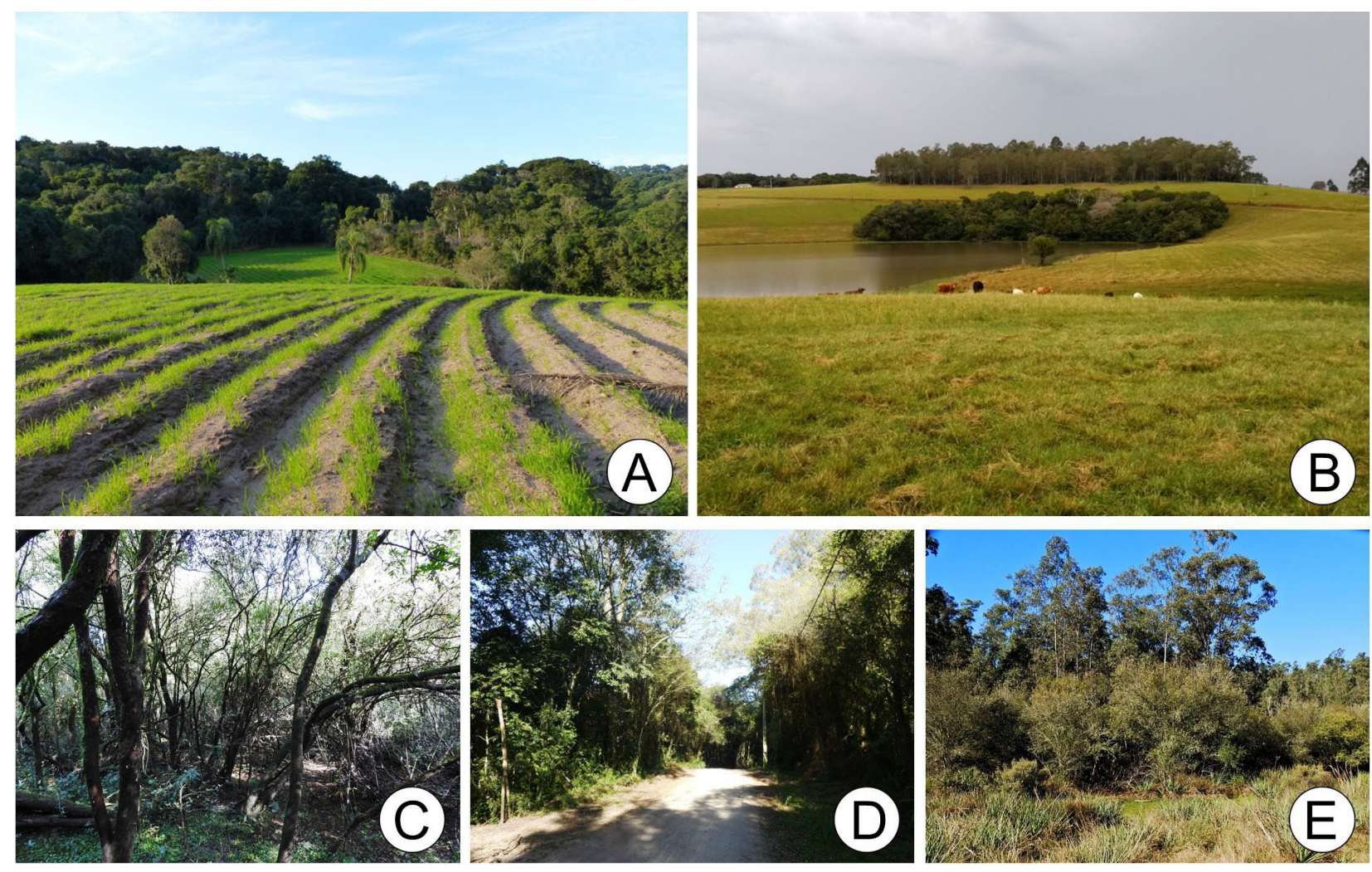

Figure 4. Landscapes of the new records localities. A. Semi-deciduous seasonal forests and agricultural areas in São Lourenço do Sul. B. Grasslands with forest fragments and Eucalyptus plantations in Sentinela do Sul. C. Riparian forest in Aceguá. D. Degraded semideciduous forest in Pelotas. E. Grasslands with bushes and Eucalyptus in Candiota. Photographs by GCG (A,D), Julianita de Moraes (B), MSW (C), and Rudimar de Matos (E).

2014), made significant contributions to our knowledge of birds in the extreme south of Brazil at the end of the 19th century (Ihering 1899), but he never deposited specimens of T. melanops collected in the Serra do Sudeste or mentioned this species for this region. In recently published lists of bird species in Rio Grande do Sul, T. melanops is only mentioned at locations north of Itapuã State Park (Accordi 2003; Accordi and Hartz 2006; Oliveira and Köhler 2010; Brummelhaus et al. 2012; Bica et al. 2014). Similarly, the online databases do not record this species south of Itapuã State Park.

In this study we discovered five new localities of occurrence of T. melanops in the extreme south of Rio Grande do Sul. The geographic range of T. melanops occurrence in Brazil is therefore expanded to the border with Uruguay with the first records of $T$. melanops for Serra do Sudeste and Campanha regions. Our Aceguá record is at the same latitude at the southern limit of the occurrence of T. melanops as the records of Marateo et al. (2009) for El Palmar National Park, Argentina. Relative to the previously known southern limit of distribution for the species, in the municipality of Viamão, both cases result in an approximate extension of $170 \mathrm{~km}$ to the south.

Marateo et al. (2009) reported two records: a female observed in June 2004 and a male observed in July 2005 and considered these records to represent vagrant. Marateo et al. (2009) suggested that these were irregular, winter occurrences for feeding and resting, with no reproduction taking place. Their records of the species are new to the National Park and of special interest. The absence of records during the reproductive season in our study strengthens Marateo et al.'s (2009) conclusion that occurrences of T. melanops in these southern latitudes are seasonal displacements of scattered individuals searching for food and do not represent a colonization front with resident populations. We observed the individual from Aceguá at several times between June 3 and September 1, and it was not seen in the locality since, which suggests displacement of this individual. Our observations of this individual were mostly from beside the home of one of us (MSW), which made its monitoring easier. These non-breeding and temporary displacements of some individuals are considered short-distance and partial migrations. This kind of movement, common in Neotropical birds, is generally driven by fluctuations in food abundance (Boyle 2011) and is possibly affected by climate change (McCarty 2001). Claramunt and Cuello (2004) reported the occurrence of T. melanops in Uruguay (Artigas province); however, Narosky and Yzurieta (2010) and Azpiroz (2012) disregarded it from that country. This was maintained by Azpiroz et al. (2012), who excluded this species from the list of birds of Uruguay due to the lack of proper documentation.

Our record in Aceguá municipality is $12 \mathrm{~km}$ from the border with Uruguay, and the record at Parque El Palmar, Uruguay (Marateo et al. 2009) is only $8 \mathrm{~km}$ from the border with Argentina. These data suggest that the 
presence of $T$. melanops in Uruguay should be better investigated, especially near the borders with Brazil and Argentina (Cerro Largo, Rivera, Artigas, Salto and Paysandu Departments).

The lack of records before 2004 at latitudes south of Viamão municipality may lead us to believe that the occurrence of T. melanops in extreme southern Brazil is a recent phenomenon, possibly driven by recent global climate change. However, it is possible that these seasonal displacements are now better documented and reported due to a growing number of birdwatchers and the availability of online databases, which makes it easier to report and divulge occurrence data.

Rodrigues (1995) demonstrated the flexibility of T. melanops in exploring different kinds of substrates, especially in the understory. Fávaro and Anjos (2005), who analysed variables in the microhabitat of $T$. melanops, suggested that this species explores diverse habitats. We found this species in riparian forests with small trees and a flora low in species richness, in predominantly grasslands, and degraded areas with a dominated by silviculture and agriculture, which suggests that $T$. melanops is able to adapt, at least in the winter, to nonforested and heavily anthropogenic habitats with fragmented vegetation.

We continue to search for T. melanops in all seasons at the localities reported here and also in other places in the Campanha and Serra do Sudeste regions. We encourage other birdwatchers and researchers to search as well, so that a better understanding can be made of this species' occurrence at the southernmost limit of its geographic distribution.

\section{Acknowledgements}

We thank Adolf Wall, Julianita D. Moraes, and Rudimar de Matos for providing field data and photographs of individuals and localities. We also thank Caio J. Carlos, Danielle Franco, and Robert Forsyth for the contributions to the manuscript.

\section{Authors' Contributions}

GCG, MSW, FPJ realized field records; GCG contacted collaborators; HNC produced the figures, GCG, TCF, FPJ, HNC, MSW wrote the manuscript.

\section{References}

Ab’Saber AN (1969) Participação das superfícies aplainadas nas paisagens do Rio Grande do Sul. Geomorfologia 11: 1-17.

Accordi IA (2003) Levantamento e análise da conservação da avifauna na sub-bacia do Baixo-Jacuí, Rio Grande do Sul, Brasil. Atualidades Ornitológicas 114: 7-28.

Accordi IA, Hartz SM (2006) Distribuição espacial e sazonal da avifauna em uma área úmida costeira do sul do Brasil. Revista Brasileira de Ornitologia 14 (2): 117-135.

Alvares CA, Stape JL, Sentelhas PC, Gonçalves JLM, Sparovek G (2013) Köppen's climate classification map for Brazil. Meteorol- ogische Zeitschrift 22 (6): 711-728. https://doi.org/10.1127/09412948/2013/0507

Azpiroz AB (2012) Aves de las pampas y campos de Argentina Brasil y Uruguay: una guía de identificación. Editora Pressur, Nueva Helvecia, $351 \mathrm{pp}$.

Azpiroz AB, Alfaro M, Jiménez S (2012) Lista Roja de las aves del Uruguay. Una evaluación del estado de conservación de la avifauna nacional con base en los criterios de Unión Internacional para la Conservación de la Naturaleza. Dirección Nacional de Medio Ambiente, Montevideo, 82 pp.

Belton W (1984) Birds of Rio Grande do Sul, Brazil. Part 1: Rheidae through Furnariidae. Bulletin of the American Museum of Natural History 178: 369-636.

Belton W (1994) Aves do Rio Grande do Sul: distribuição e biologia. Editora Unisinos, São Leopoldo, 584 pp.

Bergmann FB, Amaral HLA, Santos PRS, Gomes GC, Mauricio GN (2015) Avifauna de dois remanescentes florestais da Serra dos Tapes, Rio Grande do Sul, Brasil. Atualidades Ornitológicas 186: 33-40.

Bica JB, Konze JC, Silva DE, Corrêa LLC, Grillo HCZ (2014) Avifauna no campus do Centro Universitário Univates, Lajeado, Rio Grande do Sul, Brasil. Caderno de Pesquisa 26 (1): 29-35. https:// doi.org/10.17058/cp.v26i1.4361

Bioacoustics Research Program (2016) Raven Lite: Interactive Sound Analysis Software (Version 2.0.1). Ithaca, New York: Cornell Lab of Ornithology. http://ravensoundsoftware.com/software/ravenlite/. Accessed on: 2019-12-12.

Birdlife International (2016) Trichothraupis melanops. The IUCN Red List of threatened species 2016: e.T22722406A94765253. https://doi. org/10.2305/iucn.uk.2016-3.rlts.t22722406A94765253.en. Accessed on: 2019-07-12.

Boyle WA (2011) Short-distance partial migration of Neotropical birds: a community-level test of the foraging limitation hypothesis. Oikos 120 (12): 1803-1816. https://doi.org/10.1111/j.1600-0706. 2011.19432.x

Brummelhaus J, Bohn MS, Petry V (2012) Effect of urbanization on bird community in riparian environments in Caí River, Rio Grande do Sul, Brazil. Biotemas 25 (2): 81-96. https://doi. org/10.5007/2175-7925.2012v25n2p81

Claramunt S, Cuello JP (2004) Diversidad de la biota Uruguaya. Aves. Anales del Museo Nacional de Historia Natural y Antropología 10 (6): 1-76.

Corrêa LLC, Silva DE, Cappellari LH (2012) Avifauna do município de São Sepé, sul do Brasil. Scientia Plena 8 (9): 1-9.

Corrêa LLC, Silva DE, Pazinato DMM, Dutra CRS (2013) Levantamento preliminar da avifauna no Parque Municipal da Pedra do Segredo no Município de Caçapava do Sul, sul do Brasil. Scientia plena 9 (6): 1-7.

Costa RGA (2005) Revisão bibliográfica de recentes adições à avifauna da Campanha Gaúcha, Rio Grande do Sul. Atualidades Ornitológicas 127: 28-31.

Efe MA, Oliveira AC, Koch M, Flores JM, Scherer SB (2010) Avifauna da Área de Proteção Ambiental do Ibirapuitã, Rio Grande do Sul, Brasil. Ornithologia 2 (1): 14-24.

ESRI (2014) ArcGIS Desktop: release 10.2.2. Environmental Systems Research Institute, Redlands, California.

Faria CMA, Rodrigues M (2009) Birds and army ants in a fragment of the Atlantic Forest of Brazil. Journal of Field Ornithology 80 (4): 328-335. https://doi.org/10.1111/j.1557-9263.2009.00238.x

Fávaro FD, Anjos LD (2005) Microhabitat of Habia rubica (Vieillot) and Trichothraupis melanops (Vieillot) (Aves, Emberizidae, Thraupinae) in an Atlantic Forest, southern Brazil. Revista Brasileira de Zoologia 22 (1): 213-217. https://doi.org/10.1590/ S0101-81752005000100026

Hilty S (2019) Black-goggled Tanager (Trichothraupis melanops). In: del Hoyo J, Elliott A, Sargatal J, Christie DA, Juana E (Eds) Handbook of the birds of the world alive. Lynx Edicions, Barcelona. https://www.hbw.com/node/61610. Accessed on: 2019-12-08. 
Ihering HV (1899) As aves do Estado do Rio Grande do Sul. In: Annuario do Estado do Rio Grande do Sul para o anno 1900. Editora Gundlach \& Cia, Porto Alegre, 113-154.

IUCN Red List Technical Working Group (2019) Mapping standards and data quality for IUCN Red List spatial data. Version 1.18. Standards and Petitions Working Group of the IUCN SSC Red List Committee. https://www.iucnredlist.org/resources/mapping standards. Accessed on: 2019-12-08.

Lopes MM, Podgorny I (2014) Entre mares e continentes: aspectos da trajetória científica de Hermann von Ihering, 1850-1930. História, Ciências, Saúde - Manguinhos 21 (3): 809-826. https:// doi.org/10.1590/S0104-59702014000300002

Marateo G, Povedano H, Alonso J (2009) Inventario de las aves de Parque Nacional El Palmar, Argentina. Cotinga 31 (1): 47-60.

Mauricio GN, Dias RA (1998) Range extensions and new records for forest birds in southern Rio Grande do Sul, Brazil. Bulletin of the British Ornithologists' Club 118: 14-24.

Mauricio GN, Dias RA (2001) Distribuição e conservação da avifauna florestal na Serra dos Tapes, Rio Grande do Sul, Brasil In: Albuquerque JLB, Cândido JF, Straube FC, Roos AL (Eds) Ornitologia e conservação: da ciência às estratégias, Editora Unisul, Tubarão, 137-158.

McCarty JP (2001) Ecological consequences of recent climate change.
Conservation Biology 15 (2): 320-331. https://doi.org/10.104 6/j.1523-1739.2001.015002320

Narosky S, Yzurieta D (2010) Aves de Argentina y Uruguay: guía de identificación/Birds of Argentina \& Uruguay: a field guide. Editora Vazquez Mazzini, Buenos Aires, 427 pp.

Oliveira SL, Köhler A (2010) Avifauna da RPPN da UNISC, Sinimbu, Rio Grande do Sul, Brasil. Biotemas 23 (3): 93-103. https://doi.org/ 10.5007/2175-7925.2010v23n3p93

Pillar VP, Müller SC, Castilhos ZMS, Jacques AV (2009) Campos Sulinos: conservação e uso sustentável da biodiversidade. Ministério do Meio Ambiente, Brasília, 403 pp.

Rodrigues M (1995) Spatial distribution and food utilization among tanagers in southeastern Brazil (Passeriformes: Emberizidae). Ararajuba 3 (1): 27-32.

Seixas ALR, Silva DE, Corrêa LLC (2014) Lista atual da avifauna no município de Caçapava do Sul, sul do Brasil. Caderno de Pesquisa 26 (1): 6-14. https://doi.org/10.17058/cp.v26i1.4723

Teixeira MB, Coura-Neto AB, Pastore U, Rangel-Filho LR (1986) Vegetação: as regiões fitoecológicas, sua natureza e seus recursos econômicos; estudo fitogeográfico. In: IBGE Levantamento de Recursos. Ministério das Minas e Energia, Rio de Janeiro, 33: 541-620.

Timm CD, Timm VF (2016) Aves do extremo sul do Brasil: guia de identificação. Editora Useb, Pelotas. 334 pp. 